\title{
Recent Developments in the Use of Intralesional Injections Keloid Treatment
}

\author{
Aurelia Trisliana Perdanasari ${ }^{1 *}$, Davide Lazzeri ${ }^{2 *}$, Weijie $\mathrm{Su}^{1}$, Wenjing $\mathrm{Xi}^{1}$, Zhang Zheng ${ }^{1}$, \\ $\mathrm{Li} \mathrm{Ke}^{1}$, Peiru Min ${ }^{1}$, Shaoqing Feng ${ }^{1}$, Yixin Zhang ${ }^{1}$, Paolo Persichetti ${ }^{3}$ \\ ${ }^{1}$ Department of Plastic and Reconstructive Surgery, Shanghai Ninth People's Hospital, Shanghai JiaoTong University School of Medicine, \\ Shanghai, China; ${ }^{2}$ Plastic Reconstructive and Aesthetic Surgery Unit, Villa Salaria Clinic, Rome; ${ }^{3}$ Plastic and Reconstructive Surgery Unit, \\ Campus Bio-Medico University, Rome, Italy
}

Keloid scars are often considered aesthetically unattractive and frustrating problems that occur following injuries. They cause functional and cosmetic deformities, displeasure, itching, pain, and psychological stress and possibly affect joint movement. The combination of these factors ultimately results in a compromised quality of life and diminished functional performance. Various methods have been implemented to improve keloid scars using both surgical and non-surgical approaches. However, it has proven to be a challenge to identify a universal treatment that can deliver optimal results for all types of scars. Through a PubMed search, we explored most of the literature that is available about the intralesional injection treatment of hypertrophic scars and keloids and highlights both current (corticosteroid, 5-fluorouracil, bleomycin, interferon, cryotherapy and verapamil) and future treatments (interleukin-10 and botulinum toxin type A). The reference lists of retrieved articles were also analysed. Information was gathered about the mechanism of each injection treatment, its benefits and associated adverse reactions, and possible strategies to address adverse reactions to provide reliable guidelines for determining the optimal treatment for particular types of keloid scars. This article will benefit practitioners by outlining evidence-based treatment strategies using intralesional injections for patients with hypertrophic scars and keloids.

Keywords Keloids / Injections, intralesional / Review / Treatment outcome / Cicatrix

Received: 21 May 2014• Revised: 5 Sep $2014 \bullet$ Accepted: 12 Sep 2014

pISSN: 2234-6163 • elSSN: 2234-6171 • http://dx.doi.org/10.5999/aps.2014.41.6.620 • Arch Plast Surg 2014;41:620-629

\author{
Correspondence: Yi Xin Zhang \\ Department of Plastic and \\ Reconstructive Surgery, Shanghai \\ Ninth People's Hospital, Shanghai \\ JiaoTong University School of \\ Medicine, Shanghai 200011, China \\ Tel: +86-21-2327-1699 \\ Fax: +86-21-6305-1858 \\ E-mail: zhangyixin6688@hotmail. \\ com
}

*The first two authors equally contributed to this work.

No potential conflict of interest relevant to this article was reported.

\section{INTRODUCTION}

Keloids are a skin disorder in which the skin grows beyond the boundaries of the original wound, although keloids of unrecognized origin also occur. Traditionally, keloids have been seen as the result of aberrant wound healing involving excessive fibroblast participation that is characterised by hyalinised collagen bundles, although the usefulness of this characterisation has been questioned $[1,2]$. Keloid scars are often considered cos- metically unattractive and frustrating problems that follow injuries and cause functional and cosmetic deformities, displeasure, itching, pain, psychological stress, and patient dissatisfaction, and moreover, can possibly affect joint movement, significantly reduce quality of life, and diminish functional performance. Currently, it remains difficult to assess the effectiveness of diverse treatments for keloids because of the range of factors that influence the efficacy of treatment, including the race, age, and sex of the patient and the anatomical position of the lesion [1-3]. 
Numerous studies have investigated effective treatments for keloids, but the utility of these treatments and their efficacy when used in various combinations have not been clearly defined. In many cases, keloids result in fibrotic scars that are characterised by abnormal colours, textures, and thicknesses and should be corrected with surgical methods [2]. The methods that have been used to improve keloid scars vary considerably, ranging from surgical to non-surgical methods. In some cases, surgical approaches are inadvisable, and in such cases, intralesional injection treatments play an important role in the treatment of keloids.

Intralesional injection treatments have demonstrated some promising results over the years, including improvements in scar appearance that significantly benefit patients by minimizing the social and economic impacts of scarring and improving their psychological well-being in relation to both function and aesthetics [3]. Trends continue to evolve because many viable options exist for the treatment of pathological scarring, depending on the characteristics of the individual patient and institutional preferences. However, there is still no consensus regarding which intralesional injection techniques are optimal for keloid treatment. This article reviews the latest literature available on the subject and summarizes the mechanism of each treatment, its benefits and associated adverse reactions, and possible strategies to address adverse reactions.

\section{METHODS}

\section{Review of the evidence and recent developments (Tables 1,2) [4-14] \\ Corticosteroids}

Since the mid-1960s, corticosteroid injections, most commonly triamcinolone acetonide, have been a popular treatment for pathological scars, and this treatment continues to play a major role in the management of keloids $[14,15]$. Depending on the size and site of the lesion and on the age of the patient, the dosage has varied from 10 to $40 \mathrm{mg} / \mathrm{mL}$, and the treatment interval is administrated at intervals of 4 to 6 weeks for several months or until the scar is flattened $[16,17]$. The corticosteroid should be injected at the correct depth in the mid-dermis to avoid irreversible atrophy of the epidermis [14]. Injections should be repeated once every 3-4 weeks depending on the bulk of the keloid and the therapeutic response [16,17].

The triamcinolone injection can suppress vascular endothelial growth factor, inhibit fibroblast proliferation, and induce scar regression, which may be the most important mechanism of action [18]. The effects of corticosteroids are primarily due to their suppressive effects on the inflammatory process in the wound and secondarily due to reduced collagen and glycosaminoglycan synthesis, the inhibition of fibroblast growth, and the enhancement of collagen and fibroblast degeneration [19]. Triamcinolone has been found to inhibit transforming growth factor (TGF)- $\beta 1$ expression and to induce apoptosis in fibroblasts $[18,19]$.

Intralesional triamcinolone injections are commonly used after surgery in combination with surgical excision of the pathological scar and decrease the recurrence rates by an average of $50 \%$. The rates of response to intralesional corticosteroid injections vary from $50 \%$ to $100 \%$. Triamcinolone injection alone also is effective in reducing the volume of lesions in the majority of patients [16-19]. Previous literature has reported that mean scar volumes are reduced from $0.73 \pm 0.701 \mathrm{~mL}$ at baseline to $0.14 \pm 0.302 \mathrm{~mL}$ after monthly intralesional injections of triamcinolone acetonide [20,21].

Side effects include the pain of the injections, thinning and atrophy of the skin and subcutaneous tissues, the development of steroid acne, capillary dilation, the development of secondary lymphogenous and linear hypopigmentation (which may be permanent), and relatively high recurrence rates of $9 \%$ to $50 \%$ [12]. Park et al. [22] concluded that the anatomic location of facial keloids could play a role in re-development, because recurrence rates were greater in perioral regions. A possible reason for this greater recurrence could be skin tension and wound strain in the highly mobile perioral region [22]. Further serious side effects include local skin necrosis, ulcer formation, and Cushing syndrome [23].

The complications can be eliminated by adjusting the dosage and combining the injections with other treatments. In 2002, an international panel of experts recommended that corticosteroid doses of 2.5 to $40 \mathrm{mg}$ per site be used [24]. Surgical excision with intraoperative local injection of triamcinolone acetonide followed by repeated injections at weekly intervals for 2 to 5 weeks and further followed by monthly injections for 4 to 6 months yielded good results with very low rates of recurrence and other complications [21]. The combination of 5-fluorouracil (5-FU) and triamcinolone seems to be superior to intralesional steroid therapy alone in the treatment of keloids; an average reduction in $92 \%$ of the lesion size has been reported for this combination therapy compared to $73 \%$ for steroid therapy alone [13]. The results may be improved and scar recurrence reduced when corticosteroids are combined with other therapies such as surgery, pulsed-dye laser, radiation therapy, 5-FU, and cryotherapy $[25,26]$.

Camacho-Martínez et al. [6] combined bleomycin and triamcinolone acetonide with injections every 3 months. Contrastingly, Martin et al. [5] combined treatment with a $\mathrm{CO}_{2}$ fractional laser, a Cynergy pulsed-dye laser, and triamcinolone aceton- 
Table 1. Review of the evidence and current developments in corticosteroid intralesional injection treatments

\begin{tabular}{|c|c|c|c|c|c|c|}
\hline Study & $\begin{array}{l}\text { Type of } \\
\text { scar }\end{array}$ & $\begin{array}{c}\text { Combination } \\
\text { theraphy }\end{array}$ & $\begin{array}{l}\text { Corticosteroid } \\
\text { dosage }\end{array}$ & Interval & Result & Side effect \\
\hline $\begin{array}{l}\text { Park et al. } \\
\text { (2013) [4] }\end{array}$ & Keloids & $\begin{array}{l}\text { Surgical excision followed } \\
\text { by full-thickness skin } \\
\text { grafting combined with } \\
\text { postoperative steroid } \\
\text { injections }\end{array}$ & & $\begin{array}{l}\text { Four corticosteroid } \\
\text { injections (at one } \\
\text { month intervals) } \\
\text { postoperatively }\end{array}$ & $\begin{array}{l}\text { - } 78.5 \% \text { experienced successful } \\
\text { treatment } \\
\text { - } 21.5 \% \text { experienced recurrence }\end{array}$ & $\begin{array}{l}\text { - Recurrance } \\
\text { - Slight marginal elevation } \\
\text { and redness }\end{array}$ \\
\hline $\begin{array}{l}\text { Martin et al. } \\
\text { (2013) [5] }\end{array}$ & Keloids & $\begin{array}{l}\mathrm{CO}_{2} \text { fractional laser } \\
(10,600 \mathrm{~nm} \text {, Cynosure), } \\
\text { Cynergy pulsed dye } \\
\text { laser (585 nm, } \\
\text { Cynosure), triamcinolone } \\
\text { acetonide injection }\end{array}$ & $\begin{array}{l}\text { Triamcinolone acetonide } \\
(0.5 \mathrm{~mL}, 40 \mathrm{mg} / \mathrm{mL} 0.4 \mathrm{~mL} \\
\text { lidocaine with epinephrine) }\end{array}$ & $\begin{array}{l}\text { Once per month for } \\
\text { seven sessions }\end{array}$ & $\begin{array}{l}\text { - Minimal flatness } \\
\text { - Minimal effect on size } \\
\text { - Pruritus diminished } \\
\text { - Lighter pigmentation }\end{array}$ & NA \\
\hline $\begin{array}{l}\text { Camacho- } \\
\text { Martínez et al. } \\
\text { (2013) [6] }\end{array}$ & $\begin{array}{l}\text { Keloids and } \\
\text { hypertrophic } \\
\text { scars }\end{array}$ & $\begin{array}{l}\text { Bleomycin and } \\
\text { triamcinolone acetonide }\end{array}$ & $\begin{array}{l}4-5 \mathrm{mg} / \mathrm{cm}^{2} \text { of a } 40 \mathrm{mg} / \mathrm{mL} \\
\text { triamcinolone acetonide } \\
(0.10-0.125 \mathrm{~mL} \text { in a syringe } \\
\text { of } 0.5 \mathrm{~mL})\end{array}$ & Every 3 mo & $\begin{array}{l}\text { - Flattening } \\
\text { - Scar height reduction } \\
\text { - Softening }\end{array}$ & $\begin{array}{l}\text { - Erythema } \\
\text { - Telangiectasias } \\
\text { - Atrophy } \\
\text { - Ulceration } \\
\text { - Reoccurance }\end{array}$ \\
\hline $\begin{array}{l}\text { Son et al. } \\
\text { (2014) [7] }\end{array}$ & $\begin{array}{l}\text { Keloids and } \\
\text { hypertrophic } \\
\text { scars }\end{array}$ & $\begin{array}{l}578 \mathrm{~nm} \text { copper bromide } \\
\text { laser combined with } \\
\text { intralesional } \\
\text { corticosteroid injections }\end{array}$ & $\begin{array}{l}10 \mathrm{mg} / \mathrm{mL} \text { of triamcinolone } \\
\text { acetonide }\end{array}$ & $\begin{array}{l}\text { Combined treatment } \\
\text { at 4-week intervals }\end{array}$ & $\begin{array}{l}\text { - Reduced vascular components } \\
\text { of scars } \\
\text { - Decreased erythema } \\
\text { - Improved pruritus } \\
\text { - Improve telangiectasia } \\
8 \%=\leq 25 \% \text { improvement } \\
17 \%=25 \% \text { to } 50 \% \text { improvement } \\
33 \%=51 \% \text { to } 75 \% \text { improvement } \\
42 \%=\geq 75 \% \text { improvement }\end{array}$ & $\begin{array}{l}\text { - Moderate pain during } \\
\text { treatment } \\
\text { - Transient erythema and } \\
\text { edema } \\
\text { - Mild hyperpigmentation }\end{array}$ \\
\hline $\begin{array}{l}\text { Emad et al. } \\
\text { (2010) [8] }\end{array}$ & Keloids & $\begin{array}{l}\text { Surgical excision and } \\
\text { immediate postoperative } \\
\text { radiotherapy vs. } \\
\text { cryotherapy and } \\
\text { intralesional steroids }\end{array}$ & $\begin{array}{l}10 \mathrm{mg} / \mathrm{mL} \text { of triamcinolone } \\
\text { acetonide in each session } \\
\text { (maximum } 40 \mathrm{mg} \text { ) }\end{array}$ & Every 20 day & $\begin{array}{l}\text { - } 66.7 \% \text { satisfied } \\
\text { - 22.2\% partially satisfied } \\
\text { - } 11.1 \% \text { unsatisfied }\end{array}$ & $\begin{array}{l}\text { - Hypopigmentation (9.4\%) } \\
\text { - Ulceration+necrosis } \\
\quad(31.2 \%) \\
\text { - Telangiectasia (18.8\%) }\end{array}$ \\
\hline $\begin{array}{l}\text { Sadeghinia } \\
\text { et al. } \\
\text { (2011) [9] }\end{array}$ & Keloids & $\begin{array}{l}\text { Intralesional } \\
\text { triamcinolone acetonide } \\
\text { and 5-fluorouracil } \\
\text { tattooing }\end{array}$ & $\begin{array}{l}20 \mathrm{mg}(0.5 \mathrm{~mL}) \text { of TAC } \\
(40 \mathrm{mg} / \mathrm{mL}) \text { was injected } \\
\text { per } 1 \mathrm{~cm}^{2} \text { of the lesion. }\end{array}$ & $\begin{array}{l}\text { Every } 4 \text { wk for } \\
12 \text { wk }\end{array}$ & $\begin{array}{l}\text { - Reduced erythema and pruritus } \\
\text { - Reduced surface and height }\end{array}$ & NA \\
\hline $\begin{array}{l}\text { Al Aradi et al. } \\
\text { (2013) [10] }\end{array}$ & Keloids & $\begin{array}{l}\text { Keloidectomy with core } \\
\text { fillet flap and } \\
\text { intralesional steroid } \\
\text { injections }\end{array}$ & $\begin{array}{l}40 \mathrm{mg} / \mathrm{mL}(0.25 \mathrm{~mL}) \text { of } \\
\text { intralesional triamcinolone } \\
\text { acetonide }\end{array}$ & Monthly & $\begin{array}{l}\text { - Efficacy } 87.6 \% \\
\text { - Immediate recurrence } 9.5 \% \\
\text { - Subjectively, } 82.3 \% \text { patients were } \\
\text { highly satisfied } \\
\text { - Softness, flattening, atrophy, } \\
\text { pigmentation, and recurrence } \\
\text {-Scars were minimal in all patients }\end{array}$ & $\begin{array}{l}\text { - Full-flap necrosis } \\
\text { - Abscess-like nodule } \\
\text { - Neuroma }\end{array}$ \\
\hline $\begin{array}{l}\text { Anthony et al. } \\
(2010)[11]\end{array}$ & Keloids & $\begin{array}{l}\text { Triamcinolone } \\
\text { corticosteroid }\end{array}$ & $\begin{array}{l}\text { - Nonbearded area of the face } \\
\rightarrow \text { mean dose of steroid of } \\
8.75 \mathrm{mg} \\
\text { - The bearded area (upper limb, } \\
\text { earlobes, occipital area, } \\
\text { sternum) } \rightarrow \text { mean dose of } \\
20.37 \mathrm{mg} \\
\text { - Regimen } 1=10 \mathrm{mg} / \mathrm{mL} \text { of TAC } \\
\text { - Regimen } 2=40 \mathrm{mg} / \mathrm{mL} \\
\text { - Regimen } 3=10 \mathrm{mg} / \mathrm{mL} \\
\text { followed by } 40 \mathrm{mg} / \mathrm{mL} \\
\text { - Regimen } 4=10 \mathrm{mg} / \mathrm{mL} \text { then } \\
40 \mathrm{mg} / \mathrm{mL} \text { and then } 10 \mathrm{mg} / \mathrm{mL} \\
\text { - Regimen } 5=40 \mathrm{mg} / \mathrm{mL} \text { then } \\
10 \mathrm{mg} / \mathrm{mL}\end{array}$ & 4-week intervals & $\begin{array}{l}\text {-Triamcinolone } 10 \mathrm{mg} / \mathrm{mL} \text { followed by } \\
40 \mathrm{mg} / \mathrm{mL} \text { (Regimen } 3 \text { ) was most } \\
\text { effective, with the lowest recurrence } \\
\text { rate }(10 \%)\end{array}$ & $\begin{array}{l}\text { - Regimen } 1 \text { had } 22 \% \\
\text { recurrence } \\
\text { - Regimen } 2 \text { had } 25 \% \\
\text { recurrence } \\
\text { - Regimen } 3 \text { had 10\% } \\
\quad \text { recurrence } \\
\text { - Regimen } 4 \text { had 24\% } \\
\text { recurrence } \\
\text { - Regimen } 5 \text { had 50\% } \\
\text { recurrence }\end{array}$ \\
\hline $\begin{array}{r}\text { Niessen et al. } \\
\text { (1999) [12] }\end{array}$ & $\begin{array}{l}\text { Keloids and } \\
\text { hypertrophic } \\
\text { scars }\end{array}$ & $\begin{array}{l}\text { Triamcinolone } \\
\text { corticosteroid (review) }\end{array}$ & $10-40 \mathrm{mg} / \mathrm{mL}$ & Monthly & $\begin{array}{l}\text { - Decreased recurrence rates } \\
\text { - Decreased collagen and } \\
\text { glycosyminoglycan synthesis } \\
\text { - Reduction of inflammatory processes } \\
\text {-Decreased fibroblast proliferation }\end{array}$ & $\begin{array}{l}\text { - Atrophy } \\
\text { - Ulceration } \\
\text { - Necrosis } \\
\text { - Telangiectasia } \\
\text { - Depigmentation } \\
\text { - Cushingoid features } \\
\text { - Hypopigmentation }\end{array}$ \\
\hline $\begin{array}{l}\text { Davison et al. } \\
\text { (2011) [13] }\end{array}$ & Keloids & $\begin{array}{l}\text { 5-fluorouracil and } \\
\text { triamcinolone }\end{array}$ & $\begin{array}{l}0.1 \mathrm{~mL} \text { of solution per } \\
\text { centimeter of lesion }\end{array}$ & 4-week intervals & $\begin{array}{l}\text { - 92\% average reduction in lesion size } \\
\text { - Reduction of pruritus } \\
\text { - Pain resolved }\end{array}$ & Telangiectasias \\
\hline $\begin{array}{l}\text { Gupta et al. } \\
\text { (2011) [14] }\end{array}$ & $\begin{array}{l}\text { Keloids and } \\
\text { hypertrophic } \\
\text { scars }\end{array}$ & $\begin{array}{l}\text { 5-fluorouracil and } \\
\text { triamcinolone }\end{array}$ & $\begin{array}{l}\text { Generally } 10-20 \mathrm{mg} / \mathrm{mL} \text {, } \\
40 \mathrm{mg} / \mathrm{mL} \text { for a tough bulky } \\
\text { lesion }\end{array}$ & 3-4 wk (monthly) & - Reduced volume of lesions & Irreversible atrophy \\
\hline
\end{tabular}


Table 2. Review of the evidence and current developments in non-corticosteroid intralesional injection treatments

\begin{tabular}{|c|c|c|c|c|c|}
\hline Substance & Dosage suggested & Interval & Outcomes & Adverse reactions & Possible solutions \\
\hline $5-\mathrm{FU}$ & $40-50 \mathrm{mg} / \mathrm{mL}$ & Weekly & $\begin{array}{l}\text { 1. Improved scar height, } \\
\text { erythema, and pliability } \\
\text { 2. Histological findings: } \\
\text { - Reduction of hyalinised collagen } \\
\text { fibers } \\
\text { - Less prominent vascularity } \\
\text { - Flattening of the dermal papillae } \\
\text { without any signs of atrophy } \\
\text { - Pigmentary incontinence } \\
\text { - Reduction of Ki-67 expression } \\
\text { - Slight reduction of TGF- } \beta \\
\text { expression }\end{array}$ & $\begin{array}{l}\text { - Wound ulceration } \\
\text { - Hyperpigmentation } \\
\text { - Atrophy } \\
\text { - Erythema } \\
\text { - Tissue sloughing } \\
\text { - Swelling } \\
\text { - Pain } \\
\text { - Molting } \\
\text { - Telangiectasia } \\
\text { (mostly resolved spontaneously) }\end{array}$ & $\begin{array}{l}\text { Lowering or mixing the doses in } \\
\text { cocktail therapy: } \\
\text { - Mixing } 1 \mathrm{mg} / \mathrm{mL} \text { triamcinolone } \\
\text { (glucocorticoids) with the } 5 \text {-FU } \\
\text { - } 50 \mathrm{mg} / \mathrm{mL} 5 \text {-FU in combination } \\
\text { with } 10 \mathrm{mg} / \mathrm{mL} \text { triamcinolone or } \\
\text { with a very low concentration of } \\
\text { betamethasone ( } 5.7 \mathrm{mg} / \mathrm{mL} \text { ) } \\
\text { - Triple combination of } 5 \text {-FU, } \\
\text { corticosteroids, and PDL } \\
\text { - Above strategies result in better } \\
\text { regression without recurrence, } \\
\text { substantial flattening, and pruritus }\end{array}$ \\
\hline Bleomycin & $\begin{array}{l}\text { Multiple needle punctures } \\
\text { or jet injections of } \\
\text { bleomycin }(1.5 \mathrm{IU} / \mathrm{mL})\end{array}$ & Monthly & $\begin{array}{l}\text { - Volume and functional } \\
\text { impairment substantially } \\
\text { reduced } \\
\text { - Substantial flattening } \\
\text { - Pruritus relieved }\end{array}$ & $\begin{array}{l}\text { - Flagellate erythema (scratch } \\
\text { dermatitis) } \\
\text { - Hyperpigmentation } \\
\text { - Raynaud's phenomenon } \\
\text { - Gangrene } \\
\text { - Fibrosis } \\
\text { - Neutrophil eccrine hidradenitis } \\
\text { - Necrosis of keratinocytes } \\
\text { - Alopecia } \\
\text { - Oedema } \\
\text { - Nail changes } \\
\text { - Moderately expensive }\end{array}$ & $\begin{array}{l}\text { - Dosages were reduced to lower } \\
\text { than } 200 \mathrm{IU} \\
\text { - Multiple jet injections of } 0.1 \mathrm{~mL} \text { of } \\
\text { bleomycin ( } 1.5 \mathrm{IU} / \mathrm{mL} \text { ) were } \\
\text { administered to each lesion } \\
\text { - Multiple punctures were made with } \\
\text { a } 25 \text {-gauge needle and bleomycin } \\
\left(2 \mathrm{~mL} / \mathrm{cm}^{2}\right) \text { was dripped onto the } \\
\text { lesion } \\
\text { - Bleomycin performed better than } \\
\text { cryotherapy combined with } \\
\text { intralesional triamcinolone injection }\end{array}$ \\
\hline Interferon & $0.05 \mathrm{mg}$ of IFN-C & $\begin{array}{l}\text { Given twice daily } \\
\text { over four days } \\
\text { Injected } \\
\text { intradermally once } \\
\text { a week for } 10 \\
\text { wk }\end{array}$ & $\begin{array}{l}\text { - Reduced recurrence after } \\
\text { excision } \\
\text { - Reduced keloid surface area } \\
\text { and size }\end{array}$ & $\begin{array}{l}\text { - Flu-like symptoms } \\
\text { - Pain at injection site } \\
\text { - Local erythema } \\
\text { - Oedema } \\
\text { - Expensive }\end{array}$ & $\begin{array}{l}\text { - Flu-like symptoms can be prevented } \\
\text { by pre-treatment with } 500 \mathrm{mg} \\
\text { acetaminophen } \\
\text { - The recommendation for } \\
\text { postoperative interferon injection is } \\
1,000,000 \mathrm{IU} / \mathrm{cm} \text { of skin } \\
\text { surrounding the postoperative site } \\
\text { administered immediately after } \\
\text { surgery and } 1 \text { to } 2 \text { weeks thereafter } \\
\text { - In combination with intralesional } \\
\text { corticosteroids and the } \mathrm{CO}_{2} \text { laser, } \\
\text { the addition of interferon alpha-2b } \\
\text { lowers recurrence rates and leads } \\
\text { to better outcomes }\end{array}$ \\
\hline Cryotherapy & $\begin{array}{l}\text { intralesional cryosurgery } \\
\text { cryo-needle inserted into } \\
\text { keloid scar and } \\
\text { connected to a canister } \\
\text { of liquid nitrogen, which } \\
\text { causes the cryo-needle } \\
\text { to freeze at } 20 \mathrm{~mm} \\
\text { depth }\end{array}$ & Monthly & $\begin{array}{l}\text { - Reduced volume } \\
\text { - Improved subjective (pain, } \\
\text { itching) and objective (hardness, } \\
\text { color) ratings }\end{array}$ & $\begin{array}{l}\text { - Relatively costly } \\
\text { - Minimal hypopigmentation }\end{array}$ & $\begin{array}{l}\text { - The non-response rate of this } \\
\text { technique was less than } 3 \% \text {, thus } \\
\text { representing a promising alternative } \\
\text { scar reduction strategy } \\
\text { - Combination treatment with surgery } \\
\text { PDL, radiation therapy, and 5-FU } \\
\text { leads to a better results }\end{array}$ \\
\hline Verapamil & $\begin{array}{l}\text { Intralesional verapamil } \\
(2.5 \mathrm{mg} / \mathrm{mL}) \\
0.5 \mathrm{~mL} \text { and } 2.0 \mathrm{~mL} \text { was } \\
\text { administered each time, } \\
\text { depending on the size of } \\
\text { the keloid }\end{array}$ & $\begin{array}{l}\text { Once every 3-4 } \\
\text { wk } \\
1 \text { mo after the } \\
\text { keloid removal }\end{array}$ & $\begin{array}{l}\text { - Reduction in fibrous tissue } \\
\text { production } \\
\text { - Reduced scar vascularity, } \\
\text { pliability, height, and width } \\
\text { - Reduced the incidence of keloid } \\
\text { recurrence clinically after } \\
\text { surgical excision and topical } \\
\text { silicone application }\end{array}$ & $\begin{array}{l}\text { - Pain at injection sites } \\
\text { - High recurrence rate }\end{array}$ & $\begin{array}{l}\text { - Combination treatment with surgery, } \\
\text { corticosteroids, and laser therapy }\end{array}$ \\
\hline
\end{tabular}

ide injections to treat keloids, and they reported excellent results with minimal flatness, diminished pruritus, and lighter pigmentation. Son et al. [7] showed that $42 \%$ of patients reported $\geq 75 \%$ improvement after treatment with a $578 \mathrm{~nm}$ copper bromide laser combined with intralesional corticosteroid injections. In 2011, Sadeghinia and Sadeghinia [9] showed that intralesional triamcinolone acetonide and 5-FU tattooing effi- ciently reduce erythema, pruritus, surface, and height. Moreover, Anthony et al. [11] showed that triamcinolone concentrations of $10 \mathrm{mg} / \mathrm{mL}$ followed by $40 \mathrm{mg} / \mathrm{mL}$ were most effective, with the lowest recurrence rate (10\%). Park et al. [4] used a very interesting combination therapy in which surgical excisions were followed by full-thickness skin grafting along with postoperative steroid injections, achieving a $78.5 \%$ success rate. Emad 
et al. [8] used surgical excision and immediate postoperative radiotherapy instead of cryotherapy and intralesional steroids, but with only $66.7 \%$ satisfactory results. Al Aradi et al. [10] showed that keloidectomies combined with core fillet flaps and intralesional steroid injections resulted in $87.6 \%$ efficacy.

\section{5- Fluorouracil}

As a pyrimidine analogue, 5-FU is classified as an antineoplastic agent that inhibits normal DNA and RNA synthesis, thereby reducing thymidylate synthase activity. 5-FU has more recently been demonstrated to induce fibroblast apoptosis without necrosis and is known to inhibit TGF- $\beta$ signalling in collagen I production [27]. Rapidly proliferating and metabolising cells, such as the fibroblasts in dermal wounds that are responsible for excessive collagen production, are an alternate target of 5-FU [15,27-30].

Since 1989, 5-FU has been successful in the treatment of keloids and hypertrophic scars. In 1999, Fitzpatrick [28] improvements in the majority of 1,000 patients who were treated with intralesional 5-FU injections; however, in many of these cases, other treatment modalities, including the pulsed-dye laser and radiation therapy, were combined with intralesional corticosteroid injections.

Kontochristopoulos et al. [29] treated 20 patients with intralesional injections of 5-FU $(50 \mathrm{mg} / \mathrm{mL})$ once weekly for seven weeks and followed these patients for up for 12 months. The results revealed that $85 \%$ of the patients experienced greater than $50 \%$ improvement. Biopsy specimens taken after six injections exhibited a reduction in the amount of hyalinised collagen fibres, regression of the nodular concentric arrangement of the collagen fibres, less prominent vascularity, flattening of the dermal papillae without any signs of atrophy, pigmentary incontinence, reduction of Ki-67 expression, and a slight reduction of TGF- $\beta$ expression after treatment [29].

In 2009, Haurani et al. [30] conducted a prospective study to evaluate the efficacy of 5-FU in keloid treatment. The recurrence rate was only $19 \%$ at a 1-year follow-up for the keloid group, and the scar volumes ranged from $150 \%$ to $525 \%$ of the post-excision baseline values [30].

Some authors have reported wound ulceration and hyperpigmentation, atrophy, erythema, tissue sloughing, swelling, pain, moulting, and telangiectasia as complications [27,31]. However, these complications quickly disappear [27,31].

To minimize the side effects, lower dosages of the mixture are normally administered. Currently, the majority of studies have used the high-dose version of 5-FU therapy $(40-50 \mathrm{mg} / \mathrm{mL})$, although some researchers that reported that the low-dose therapy $(1.4-3.5 \mathrm{mg} / \mathrm{mL})$ is effective $[32,33]$. Fitzpatrick [28] was the first to report the use of mixed $1 \mathrm{mg} / \mathrm{mL}$ triamcinolone and 5-FU, which resulted in improved efficacy and less painful injections. An intralesional injection of $50 \mathrm{mg} / \mathrm{mL} 5-\mathrm{FU}$ in combination with $10 \mathrm{mg} / \mathrm{mL}$ triamcinolone or with a very low concentration of betamethasone $(5.7 \mathrm{mg} / \mathrm{mL})$ results in better regression, with significant flattening and pruritus, and without the recurrence of keloid scars $<2 \mathrm{~cm}$ in diameter [27].

There is sufficient evidence to suggest that the combination of 5-FU and triamcinolone is superior to triamcinolone alone ( $15 \%$ vs. $40 \%$ ), as reported by Davison et al. [13]. Several studies have demonstrated that this combination results in less skin atrophy and telangiectasia than triamcinolone alone [16]. Furthermore, it has been suggested that the triple combination of 5-FU, corticosteroids, and the pulsed-dye laser is even more effective in the treatment of keloids. Fibroblast activity is suppressed by 5-FU, corticosteroids suppress inflammation and fibroblast activity, and the pulsed-dye laser suppresses angiogenesis and endothelial cells [34].

\section{Bleomycin}

Bleomycin sulphate is thought to reduce collagen synthesis, to increase degradation secondary to the inhibition of lysyl oxidase, a cross-linking enzyme involved in the maturation of collagen and TGF- $\beta 1$, and to induce fibroblast apoptosis [35]. The main mode of action through which bleomycin blocks the cell cycle is via the inhibition of DNA synthesis, RNA, and protein synthesis as well as the production of reactive oxygen species [34]. Bleomycin is commonly used as a treatment for warts, hypertrophic scars, and keloids. It is administered either by intralesional injections or by multiple punctures using a 22-gauge needle [36].

Bodokh and Brun [36] treated 31 keloids with three to five intralesional infiltrations of bleomycin and observed a total regression of $84 \%$. The intradermal administration of bleomycin was used to treat 31 keloids, and three to five intralesional infiltrations of bleomycin were administered within one month. The keloid volumes and functional impairments were significantly reduced [36]. Espana et al. [37] administered bleomycin through multiple superficial needle punctures. In each case, the maximum dose applied was $2 \mathrm{~mL} / \mathrm{cm}^{2}$ of skin treated with a concentration of 1.5 $\mathrm{IU} / \mathrm{mL}$, and a maximum of $6 \mathrm{~mL}$ of bleomycin was given per session [37]. Substantial improvement occurred in $100 \%$ of lesions ( $\mathrm{n}=13)$, after one to five sessions of treatment with two recurrences at the 1-year follow-up [37]. In a larger 50-patient study of keloids and hypertrophic scars using the same multipuncture tattooing technique, Aggarwal et al. [38] reported that approximately $66 \%$ of lesions displayed significant or complete scar flattening with a $14 \%$ recurrence rate and that pruritus was completely relieved in $89 \%$ of the patients. In 2005 , Saray and 
Gulec [39] evaluated the effects of bleomycin on 15 keloids treated with intralesional multiple jet injections of $0.1 \mathrm{~mL}$ bleomycin $(1.5 \mathrm{IU} / \mathrm{mL})$ in each lesion. This treatment resulted in complete flattening in $73.3 \%$ of the lesions, highly significant flattening in $6.7 \%$, significant flattening in $13.3 \%$, and moderate flattening in $6.7 \%$ of the lesions [39]. In 2006, Naeini et al. [40] reported a multiple puncture technique performed on keloids with a 25 -gauge needle through which bleomycin $\left(2 \mathrm{~mL} / \mathrm{cm}^{2}\right)$ was dripped into the lesion. This technique resulted in an $88 \%$ regression of lesions with areas less than $100 \mathrm{~mm}^{2}$ [40].

Cutaneous side effects, including flagellate erythema (scratch dermatitis), hyperpigmentation, Raynaud's phenomenon, gangrene, fibrosis, neutrophil eccrine hidradenitis, necrosis of keratinocytes, alopecia, edema, nail changes, and other miscellaneous reactions have been documented [41]. It is reported that cutaneous toxicity typically occurs at total doses of 200 to 300 IU and that pulmonary fibrosis occurs at doses exceeding 400 IU [41]. The most common complications are minor ulcerations that heal within 10 days and hyperpigmentation that resolves after one year of follow-up $[38,39]$.

\section{Interferon}

Interferon (IFN) is a cytokine with antifibrotic, antiviral, and antiproliferative properties. It is widely known to decrease the synthesis of collagen I and III. IFN- $\alpha 2$ is also known to increase collagenase production [42]. IFN- $\alpha 2 \mathrm{~b}$ has been shown to prevent hypertrophic scars and keloids by inhibiting cell proliferation and TGF- $\beta 1$ expression but not by inducing myofibroblast apoptosis [42]. However, the limited efficacy of intralesional therapy might be related to the increase in circulating fibrogenic factors such as TGF- $\beta$ or N[tau]-methylhistamine [43]. Specifically, IFN- $\alpha 2 b$ has been proposed to have antiproliferative properties, which might improve the pathologic features of dermal fibrosis directly or via the antagonism of the effects of TGF- $\beta$ and histamine [43].

Intralesional injection of IFN- $\alpha 2 \mathrm{~b}$ ( 1.5 million IU, given twice daily over four days) resulted in a 50\% reduction in keloid size after only nine days and was evidently more effective than intralesional corticosteroids [44]. Additionally, a study by Larrabee et al. [45] reported that $0.05 \mathrm{mg}$ of IFN-c injected intradermally once a week for 10 weeks was safe and effective (almost 50\% achieving $\geq 50 \%$ improvement), resulting in moderate size reduction and softening of the keloid lesions. In a study conducted by Berman and Flores [46] in 1997, the injection of IFN- $\alpha 2 b$ into keloidal excision sites resulted in significantly fewer recurrences $(18.7 \%)$ compared to triamcinolone acetonide (58.5\%) and excision alone (51.2\%). Lastly, in an uncontrolled series of 30 patients treated with $\mathrm{CO}_{2}$ laser excision of keloids and adju- vant intralesional INF- $\alpha 2 b$, Conejo-Mir et al. [47] reported a $66 \%$ success rate across a long-term follow-up.

Success with this modality varies and systemic side effects may occur, including flu-like symptoms and other unfavourable reactions such as pain at the injection site, local erythema, and oede$\mathrm{ma}$ [17]. A prospective-controlled clinical trial by Davison et al. [13] investigated the efficacy of IFN- $\alpha 2 b$ as a post-excisional adjuvant therapy for keloids and reported that this approach was not effective in treating keloids. Recurrence occurred in seven of the 13 in the IFN- $\alpha 2 b$ group and four of the 26 in the triamcinolone group [13]. al-Khawajah [48] also reported two patients with severe systemic symptoms such as fever, headache, arthralgias, fatigue, chills, and confusion and found that the remainder of the patients experienced some degree of mild flulike symptoms, which led to the conclusion that this was considered a high-cost therapy.

The side effect of flu-like symptoms can be prevented by pretreatment with $500 \mathrm{mg}$ acetaminophen [49]. The recommendation for postoperative interferon injection is $1,000,000 \mathrm{IU} /$ $\mathrm{cm}^{2}$ of skin surrounding the postoperative site, administered immediately after surgery and one to two weeks thereafter [50]. In combination with other modalities, such as intralesional triamcinolone acetate and $\mathrm{CO}_{2}$ lasers, IFN- $\alpha 2 \mathrm{~b}$ lowers recurrence rates and leads to good outcomes $[35,47]$.

\section{Cryotherapy}

Cryotherapy has been used to treat keloids either as a monotherapy or in combination with intralesional triamcinolone injections. In 1994, Layton et al. [51] showed in a randomized clinical trial that vascular lesions showed a significant response to cryotherapy but that this effect was limited to small regions. Histologically, intralesional cryotherapy may cause a reduction in myofibroblasts and mast cells, in addition to the normalization of collagen structure and organization [52]. Recently, intralesional cryosurgical cryoneedles have been introduced. The needle is inserted into the keloid scar and is connected to a canister of liquid nitrogen, which causes the cryoneedle to freeze and consequently freezes the scar tissue from the inside out. Significant alleviation of clinical symptoms was achieved using this technique [52]. Intralesional cryosurgery transforms the scar architecture: the collagen fibres become aligned in a more parallel arrangement and the structure mimics a normal, organized dermis [52].

In 2004, Zouboulis et al. [53] introduced an intralesional needle cryosurgery device for both hypertrophic scars and keloids. These authors reported a 51\% average reduction in lesion volume and significantly improved subjective (pain, itching) and objective (hardness, colour) ratings [53]. This method is more effective for treating the deeper parts of scars and larger and 
bulkier keloids [15]. An average of 51\% scar volume reduction was achieved following a single cryogenic treatment [53]. In another recent study, scar volume reductions of $70 \%$ for ear keloids and $60 \%$ for keloids on the upper back, shoulder, and chest were achieved following single cryosessions [54].

Further basic research should be performed to explain these discrepancies. Although this technology is relatively costly, it appears comparatively cost-effective because a single cryo-session is frequently sufficient to induce significant improvement in keloids [51-54]. No worsening or infection of the treated scars has been noted, and only minimal hypopigmentation is evident [51-54]. The non-response rate of this technique is less than $3 \%$; thus, this technique represents a promising alternative scar reduction strategy [54].

\section{Verapamil}

Verapamil is a phenylalkylamine calcium channel blocker antiarrhythmic agent that alters fibroblast shape (from bipolar to spherical), induces procollagenase expression, inhibits the synthesis/secretion of extracellular matrix molecules, including collagen, glycosaminoglycans, and fibronectin, and increases collagenase [55]. Increased cytokine (interleukin) IL-6 and vascular endothelial growth factor levels have been shown to be expressed in fibroblasts from keloids and to contribute to matrix abnormalities and cell proliferation [56-58]. In cell cultures, verapamil has been observed to decrease IL- 6 and vascular endothelial growth factor production in the central keloid fibroblasts, which translates to decreased cell proliferation, increased apoptosis, and increased expression of decorin, which is an inhibitor of fibroblast proliferation and migration [56]. Decorin may be present in low amounts in hypertrophic and keloid scars. When added to intralesional triamcinolone, the calcium channel blocker verapamil has been shown to augment decorin expression in animal models [59].

Lawrence [58] found that excision of keloids followed by pressure dressings and intralesional verapamil resulted in a $55 \%$ reduction in keloid scarring at an average follow-up interval of 28 months. D'Andrea et al. [59] found that adjuvant verapamil helped to reduce the incidence of keloid recurrence after surgical excision and topical silicone application. A single-blind, parallel-group study demonstrated that intralesional verapamil was comparable to intralesional triamcinolone acetonide in the treatment of keloids. Both were found to produce similar results (i.e., reductions of scar vascularity, pliability, height, and width) [60]. Intralesional triamcinolone achieved these effects faster but also had a greater incidence of adverse reactions than intralesional verapamil did [60].

\section{Future directions of treatment}

Several other modalities for the intralesional injection treatment of keloids and hypertrophic scars have been investigated, many of which are in the early stages and may prove to be viable therapies in the future.

\section{Interleukin-10}

IL-10 is a cytokine that reduces inflammatory responses. IL-10 is necessary for scarless wound repair, and its anti-inflammatory effects are mediated through reductions of IL-6 and IL-8, which are proinflammatory cytokines [61].

The absence of IL-10 leads to an amplified inflammatory response and abnormal collagen deposition. An adult murine model of wound healing revealed that injection of IL-10 48 hours before wounding led to decreased inflammation and decreased expression of proinflammatory mediators compared to controls [62]. At 3 weeks, the treated wounds showed decreased inflammation, normal dermal architecture, and no abnormal collagen deposition [62].

\section{Botulinum toxin type $\mathrm{A}$}

Botulinum toxin type A (BTX-A) is a potent neurotoxin derived from Clostridium botulinum that causes the flaccid paralysis of striated muscle by inhibiting acetylcholine release at the neuromuscular junction. BTX-A is an accepted standard treatment for upper face rejuvenation [63]. BTA immobilises local muscles and reduces skin tension caused by muscle pull, thus decreasing microtrauma and subsequent inflammation [64]. The reduction of the tensile force during the course of cicatrisation and the effective regulation of the balance between fibroblast proliferation and cellular apoptosis may represent a novel therapeutic option for the aesthetic improvement of post-surgical scars.

In 2006, Gassner et al. [65] demonstrated that BTX injections into the musculature adjacent to the wound (15 IU of BTX-A, Allergan) resulted in enhanced wound healing and less noticeable scars. In one in vitro study, fibroblasts from eight keloids were treated with BTX-A. Measurements of the cell cycle distributions demonstrated that notably higher numbers of experimental fibroblasts (64\%) were in the non-proliferative phases (G0 and G1) compared to the control (36\%) [66]. The same author conducted a prospective, uncontrolled study to evaluate the effects of BTA in the treatment of ear keloids with a 24-gauge needle [67]. Per session, 70-140 IUs of BTX-A were injected intralesionally into 12 ear keloids in three sessions once a month. The results were excellent in three patients, good in five patients, and fair in four patients after 1 year of follow-up. However, there was no failure of therapy or signs of recurrence. In 2008, another study confirmed the ability of BTX-A to reduce the expression 
of TGF- $\beta 1$ in keloid fibroblasts [67]. Transforming growth factor $\beta 1$ is thought to be the main regulator of the pathogenesis of keloids and is associated with an excessive deposition of scar tissue and fibrosis [68]. In a 2009 study by Xiao et al. [69], singledose treatments with BTX-A at $2.5 \mathrm{IU} / \mathrm{cm}^{3}$ of lesion at 1-month intervals (not exceeding $100 \mathrm{IU}$ per patient) were used in $19 \mathrm{pa}-$ tients. At six months post-treatment, all patients reported decreases in erythema, itching sensations, and pliability. Haubner et al. [70] recently tested patient-specific keloid tissue in a cell culture model to determine the effects of BTX-A incubation on cell proliferation and the expression of cytokines and growth factors such as IL-6, vascular endothelial growth factor, and TGF- $\beta$. They showed that none of the tested parameters of human keloid tissue were affected by BTX-A incubation and concluded that there was no evidence to suggest a significant therapeutic role for BTX-A injections in the treatment of keloids [70]. BTX-A also has analgesic properties that are not yet completely understood, but may disrupt the neuropathic painful symptoms that are present in some keloids [71].

No serious adverse reactions of this treatment have been reported. BTX-A appears to be a safe and effective potential treatment option that can influence cellular apoptosis and proliferation to favour a cellular state that ultimately leads to the prevention and treatment of keloids.

\section{CONCLUSIONS}

The present overview summarizes current intralesional treatment strategies for keloid and hypertrophic scars along with future perspectives. This overview will benefit practitioners by providing evidence-based treatment strategies using intralesional injections for patients with hypertrophic scars and keloids.

Many treatment options have already been described in the literature, although there is no universally accepted treatment resulting in permanent hypertrophic or keloid scar ablation. Nonetheless, although no definitive conclusions could be presented about the relative effectiveness of various techniques, we highlighted some results with implications for routine clinical practice. Recent studies combining various traditional treatments and ongoing investigations of novel modalities may provide new perspectives on the treatment of scarring. Further investigation will shed light on the mechanism of scarring and will offer more techniques to effectively prevent and treat pathological scars.

\section{REFERENCES}

1. Huang C, Murphy GF, Akaishi S, et al. Keloids and hypertrophic scars: update and future directions. Plast Reconstr
Surg Glob Open 2013;1:e25.

2. Ogawa R. The most current algorithms for the treatment and prevention of hypertrophic scars and keloids. Plast Reconstr Surg 2010;125:557-68.

3. Klinger M, Marazzi M, Vigo D, et al. Fat injection for cases of severe burn outcomes: a new perspective of scar remodeling and reduction. Aesthetic Plast Surg 2008;32:465-9.

4. Park TH, Park JH, Chang $\mathrm{CH}$. Clinical features and outcomes of foot keloids treated using complete surgical excision and full thickness skin grafting followed by corticosteroid injections. J Foot Ankle Res 2013;6:26.

5. Martin MS, Collawn SS. Combination treatment of $\mathrm{CO} 2$ fractional laser, pulsed dye laser, and triamcinolone acetonide injection for refractory keloid scars on the upper back. J Cosmet Laser Ther 2013;15:166-70.

6. Camacho-Martinez FM, Rey ER, Serrano FC, et al. Results of a combination of bleomycin and triamcinolone acetonide in the treatment of keloids and hypertrophic scars. An Bras Dermatol 2013;88:387-94.

7. Son IP, Park KY, Kim B, et al. Pilot study of the efficacy of $578 \mathrm{~nm}$ copper bromide laser combined with intralesional corticosteroid injection for treatment of keloids and hypertrophic scars. Ann Dermatol 2014;26:156-61.

8. Emad M, Omidvari S, Dastgheib L, et al. Surgical excision and immediate postoperative radiotherapy versus cryotherapy and intralesional steroids in the management of keloids: a prospective clinical trial. Med Princ Pract 2010;19:402-5.

9. Sadeghinia A, Sadeghinia S. Comparison of the efficacy of intralesional triamcinolone acetonide and 5-fluorouracil tattooing for the treatment of keloids. Dermatol Surg 2012; 38:104-9.

10. Al Aradi IK, Alawadhi SA, Alkhawaja FA, et al. Earlobe keloids: a pilot study of the efficacy of keloidectomy with core fillet flap and adjuvant intralesional corticosteroids. Dermatol Surg 2013;39:1514-9.

11. Anthony ET, Lemonas P, Navsaria HA, et al. The cost effectiveness of intralesional steroid therapy for keloids. Dermatol Surg 2010;36:1624-6.

12. Niessen FB, Spauwen PH, Schalkwijk J, et al. On the nature of hypertrophic scars and keloids: a review. Plast Reconstr Surg 1999;104:1435-58.

13. Davison SP, Dayan JH, Clemens MW, et al. Efficacy of intralesional 5-fluorouracil and triamcinolone in the treatment of keloids. Aesthet Surg J 2009;29:40-6.

14. Gupta S, Sharma VK. Standard guidelines of care: Keloids and hypertrophic scars. Indian J Dermatol Venereol Leprol 2011;77:94-100.

15. Chen MA, Davidson TM. Scar management: prevention 
and treatment strategies. Curr Opin Otolaryngol Head Neck Surg 2005;13:242-7.

16. Manuskiatti W, Fitzpatrick RE. Treatment response of keloidal and hypertrophic sternotomy scars: comparison among intralesional corticosteroid, 5-fluorouracil, and 585-nm flashlamp-pumped pulsed-dye laser treatments. Arch Dermatol 2002;138:1149-55.

17. Mustoe TA, Cooter RD, Gold MH, et al. International clinical recommendations on scar management. Plast Reconstr Surg 2002;110:560-71.

18. Wu WS, Wang FS, Yang KD, et al. Dexamethasone induction of keloid regression through effective suppression of VEGF expression and keloid fibroblast proliferation. J Invest Dermatol 2006;126:1264-71.

19. Boyadjiev C, Popchristova E, Mazgalova J. Histomorphologic changes in keloids treated with Kenacort. J Trauma 1995; 38:299-302.

20. Muneuchi G, Suzuki S, Onodera M, et al. Long-term outcome of intralesional injection of triamcinolone acetonide for the treatment of keloid scars in Asian patients. Scand J Plast Reconstr Surg Hand Surg 2006;40:111-6.

21. Atiyeh BS. Nonsurgical management of hypertrophic scars: evidence-based therapies, standard practices, and emerging methods. Aesthetic Plast Surg 2007;31:468-92.

22. Park TH, Seo SW, Kim JK, et al. Clinical characteristics of facial keloids treated with surgical excision followed by intra- and postoperative intralesional steroid injections. Aesthetic Plast Surg 2012;36:169-73.

23. Shaffer JJ, Taylor SC, Cook-Bolden F. Keloidal scars: a review with a critical look at therapeutic options. J Am Acad Dermatol 2002;46:S63-97.

24. Ogawa R, Akaishi S, Izumi M. Histologic analysis of keloids and hypertrophic scars. Ann Plast Surg 2009;62:104-5.

25. Alster TS, Williams CM. Treatment of keloid sternotomy scars with $585 \mathrm{~nm}$ flashlamp-pumped pulsed-dye laser. Lancet 1995;345:1198-200.

26. Boutli-Kasapidou F, Tsakiri A, Anagnostou E, et al. Hypertrophic and keloidal scars: an approach to polytherapy. Int J Dermatol 2005;44:324-7.

27. Apikian M, Goodman G. Intralesional 5-fluorouracil in the treatment of keloid scars. Australas J Dermatol 2004;45: 140-3.

28. Fitzpatrick RE. Treatment of inflamed hypertrophic scars using intralesional 5-FU. Dermatol Surg 1999;25:224-32.

29. Kontochristopoulos G, Stefanaki C, Panagiotopoulos A, et al. Intralesional 5-fluorouracil in the treatment of keloids: an open clinical and histopathologic study. J Am Acad Dermatol 2005;52:474-9.
30. Haurani MJ, Foreman K, Yang JJ, et al. 5-Fluorouracil treatment of problematic scars. Plast Reconstr Surg 2009;123: $139-48$.

31. Wang XQ, Liu YK, Wang ZY, et al. Antimitotic drug injections and radiotherapy: a review of the effectiveness of treatment for hypertrophic scars and keloids. Int J Low Extrem Wounds 2008;7:151-9.

32. Liu W, Wu X, Gao Z, et al. Remodelling of keloid tissue into normal-looking skin. J Plast Reconstr Aesthet Surg 2008;61: 1553-4.

33. Wu XL, Liu W, Cao YL. Clinical study on keloid treatment with intralesional injection of low concentration 5-fluorouracil. Zhonghua Zheng Xing Wai Ke Za Zhi 2006;22:44-6.

34. Wang XQ, Liu YK, Qing C, et al. A review of the effectiveness of antimitotic drug injections for hypertrophic scars and keloids. Ann Plast Surg 2009;63:688-92.

35. Vivas AC, Tang JC, Maderal AD, et al. Hypertrophic scars and keloids, part 1: conventional treatments. Cosmet Dermatol 2012;25:309-16.

36. Bodokh I, Brun P. Treatment of keloid with intralesional bleomycin. Ann Dermatol Venereol 1996;123:791-4.

37. Espana A, Solano T, Quintanilla E. Bleomycin in the treatment of keloids and hypertrophic scars by multiple needle punctures. Dermatol Surg 2001;27:23-7.

38. Aggarwal H, Saxena A, Lubana PS, et al. Treatment of keloids and hypertrophic scars using bleom. J Cosmet Dermatol 2008; 7:43-9.

39. Saray Y, Gulec AT. Treatment of keloids and hypertrophic scars with dermojet injections of bleomycin: a preliminary study. Int J Dermatol 2005;44:777-84.

40. Naeini FF, Najafian J, Ahmadpour K. Bleomycin tattooing as a promising therapeutic modality in large keloids and hypertrophic scars. Dermatol Surg 2006;32:1023-9.

41. Templeton SF, Solomon AR, Swerlick RA. Intradermal bleomycin injections into normal human skin. A histopathologic and immunopathologic study. Arch Dermatol 1994; 130:577-83.

42. Xu SJ, Teng JY, Xie J, et al. Comparison of the mechanisms of intralesional steroid, interferon or verapamil injection in the treatment of proliferative scars. Zhonghua Zheng Xing Wai Ke Za Zhi 2009;25:37-40.

43. Tredget EE, Shankowsky HA, Pannu R, et al. Transforming growth factor-beta in thermally injured patients with hypertrophic scars: effects of interferon alpha-2b. Plast Reconstr Surg 1998;102:1317-28.

44. Berman B, Duncan MR. Short-term keloid treatment in vivo with human interferon alfa- $2 \mathrm{~b}$ results in a selective and persistent normalization of keloidal fibroblast collagen, gly- 
cosaminoglycan, and collagenase production in vitro. J Am Acad Dermatol 1989;21:694-702.

45. Larrabee WF Jr, East CA, Jaffe HS, et al. Intralesional interferon gamma treatment for keloids and hypertrophic scars. Arch Otolaryngol Head Neck Surg 1990;116:1159-62.

46. Berman B, Flores F. Recurrence rates of excised keloids treated with postoperative triamcinolone acetonide injections or interferon alfa-2b injections. J Am Acad Dermatol 1997;37: 755-7.

47. Conejo-Mir JS, Corbi R, Linares M. Carbon dioxide laser ablation associated with interferon alfa- $2 \mathrm{~b}$ injections reduces the recurrence of keloids. J Am Acad Dermatol 1998;39: 1039-40.

48. al-Khawajah MM. Failure of interferon-alpha $2 \mathrm{~b}$ in the treatment of mature keloids. Int J Dermatol 1996;35:515-7.

49. Jones GJ, Itri LM. Safety and tolerance of recombinant interferon alfa-2a (Roferon-A) in cancer patients. Cancer 1986; 57:1709-15.

50. Kelly AP. Medical and surgical therapies for keloids. Dermatol Ther 2004;17:212-8.

51. Layton AM, Yip J, Cunliffe WJ. A comparison of intralesional triamcinolone and cryosurgery in the treatment of acne keloids. Br J Dermatol 1994;130:498-501.

52. Har-Shai Y, Amar M, Sabo E. Intralesional cryotherapy for enhancing the involution of hypertrophic scars and keloids. Plast Reconstr Surg 2003;111:1841-52.

53. Zouboulis CC, Rosenberger AD, Forster T, et al. Modification of a device and its application for intralesional cryosurgery of old recalcitrant keloids. Arch Dermatol 2004;140: 1293-4.

54. Tziotzios C, Profyris C, Sterling J. Cutaneous scarring: Pathophysiology, molecular mechanisms, and scar reduction therapeutics Part II. Strategies to reduce scar formation after dermatologic procedures. J Am Acad Dermatol 2012;66:13-24.

55. Copcu E, Sivrioglu N, Oztan Y. Combination of surgery and intralesional verapamil injection in the treatment of the keloid. J Burn Care Rehabil 2004;25:1-7.

56. Giugliano G, Pasquali D, Notaro A, et al. Verapamil inhibits interleukin- 6 and vascular endothelial growth factor production in primary cultures of keloid fibroblasts. Br J Plast Surg 2003;56:804-9.

57. Yang JY, Huang CY. The effect of combined steroid and calcium channel blocker injection on human hypertrophic scars in animal model: a new strategy for the treatment of hypertrophic scars. Dermatol Surg 2010;36:1942-9.
58. Lawrence WT. Treatment of earlobe keloids with surgery plus adjuvant intralesional verapamil and pressure earrings. Ann Plast Surg 1996;37:167-9.

59. D’Andrea F, Brongo S, Ferraro G, et al. Prevention and treatment of keloids with intralesional verapamil. Dermatology 2002;204:60-2.

60. Margaret Shanthi FX, Ernest K, Dhanraj P. Comparison of intralesional verapamil with intralesional triamcinolone in the treatment of hypertrophic scars and keloids. Indian J Dermatol Venereol Leprol 2008;74:343-8.

61. Liechty KW, Kim HB, Adzick NS, et al. Fetal wound repair results in scar formation in interleukin-10-deficient mice in a syngeneic murine model of scarless fetal wound repair. J Pediatr Surg 2000;35:866-72.

62. Hanasono MM, Kita M, Mikulec AA, et al. Autocrine growth factor production by fetal, keloid, and normal dermal fibroblasts. Arch Facial Plast Surg 2003;5:26-30.

63. Liu RK, Li CH, Zou SJ. Reducing scar formation after lip repair by injecting botulinum toxin. Plast Reconstr Surg 2010; 125:1573-4.

64. Viera MH, Amini S, Valins W, et al. Innovative therapies in the treatment of keloids and hypertrophic scars. J Clin Aesthet Dermatol 2010;3:20-6.

65. Gassner HG, Brissett AE, Otley CC, et al. Botulinum toxin to improve facial wound healing: a prospective, blinded, placebo-controlled study. Mayo Clin Proc 2006;81:1023-8.

66. Zhibo X, Miaobo Z. Botulinum toxin type A affects cell cycle distribution of fibroblasts derived from hypertrophic scar. J Plast Reconstr Aesthet Surg 2008;61:1128-9.

67. Zhibo X, Miaobo Z. Intralesional botulinum toxin type A injection as a new treatment measure for keloids. Plast Reconstr Surg 2009; 124:275e-277e.

68. Xiao Z, Zhang F, Lin W, et al. Effect of botulinum toxin type A on transforming growth factor betal in fibroblasts derived from hypertrophic scar: a preliminary report. Aesthetic Plast Surg 2010;34:424-7.

69. Xiao Z, Zhang F, Cui Z. Treatment of hypertrophic scars with intralesional botulinum toxin type A injections: a preliminary report. Aesthetic Plast Surg 2009;33:409-12.

70. Haubner F, Leyh M, Ohmann E, et al. Effects of botulinum toxin A on patient-specific keloid fibroblasts in vitro. Laryngoscope 2014;124:1344-51.

71. Maderal AD, Tang JC, Vivas AC, et al. Hypertrophic scars and keloids, part 2: newer and investigational therapies. Cosmet Dermatol 2012;25:373-9. 